\title{
Pembuatan Minuman Herbal Sederhana Dari Jahe Untuk Mendukung Imunitas Melawan Covid-19
}

\author{
Budiyanti Wiboworini ${ }^{1}$, Joko Sudarsono ${ }^{1}$, Widardo ${ }^{1}$, Amalina Shabrina ${ }^{1}$, Yulia \\ Lanti RD ${ }^{1}$, Amelya Aughustina A ${ }^{1}$, Dwi Rahayu', Risalina Myrtha ${ }^{1}$, Sutartinah S. \\ Handayani $^{1}$
}

1. Fakultas Kedokteran, Universitas Sebelas Maret

\begin{abstract}
ABSTRAK
Pendahuluan: Penularan penyakit infeksi termasuk Covid-19 tidak terlepas dari interaksi antara agen penyebab penyakit -host dan lingkungan. Upaya peningkatan daya tahan tubuh host agar dapat bertahan terhadap serangan virus juga merupakan hal yang penting dilakukan, antara lain dengan pemanfaatan bahan alam. Jahe merupakan salah satu bahan alam yang telah terbukti dapat memperkuat imunitas. Pada masa pandemi dibutuhkan banyak agen penggerak yang bisa menularkan pengetahuan yang didapatnya ke lingkungan sekitarnya, dan remaja masjid adalah salah satu kelompok yang memenuhi kriteria tersebut. Kegiatan ini dimaksudkan menyampaikan pada remaja masjid manfaat jahe untuk memperkuat imunitas dan cara mengolahnya menjadi minuman yang segar dan enak dikonsumsi.

Metode: Kegiatan dilakukan melalui tahapan assessment, koordinasi dan pelaksanaan edukasi. Edukasi diikuti 45 remaja masjid dan takmir masjid Asy Syakur, Buran, Tasikmadu Karanganyar dengan metode ceramah dan demonstrasi pembuatan minuman jahe.

Hasil: Peserta antusias mendapatkan pemahaman, terlihat dari sesi diskusi. Peserta menyatakan mendapat pengetahuan baru dalam pemanfaatan bahan alam menjadi jamu untuk meningkatkan imunitas. Selain itu minuman yang dibuat telah dicoba dan dapat diterima karena rasanya enak dan segar.

Kesimpulan: Jahe dapat dimanfaatkan sebagai minuman herbal sederhana yang mudah dibuat dan dapat diterima masyarakat.
\end{abstract}

Kata kunci: herbal; jahe; imunitas; remaja masjid

\begin{abstract}
Introductions: The transmission of infectious diseases including Covid-19 correlate with the host, agent and environmental interactions. Strengthening the host's immunity against viruses is a priority which can be achieved with the consumption of natural ingredients. Ginger is one of the natural ingredients that have been clinically proven to increase immune system. During the pandemic, Mosque Youth can act as agents of change to share the newly-gained information about this topic. This activity aims to deliver short, educational lecture to Mosque Youth on the benefits of ginger to strengthen immunity and how to further process it into fresh and delicious drinks.

Method: The activity was implemented through the assessment, coordination and educational session. The participants were 45 Mosque Youth and Takmir of Mosque Asy Syakur, Buran, Tasikmadu Karanganyar. The delivery method of the educational session was short lectures and demonstrations on how to make the ginger drinks.

Results: The participants shown enthusiasm during the activity and claimed to successfully gained new information on processing natural ingredients into herbs to increase immunity. In addition, the drinks were consumed and appreciated by participants for the taste and freshness.

Conclusion: Ginger can be utilized as a simple, easily-made herbal drink which is much appreciated by public.
\end{abstract}

Keywords: herbs, ginger, immunity, mosque youth

Correspondence: Amalina Shabrina, S.Gz., M.Sc., Fakultas Kedokteran UNS, Email amalina.shabrina@staff.uns.ac.id 


\section{PENDAHULUAN}

Meskipun telah berlangsung lebih dari satu tahun, angka kejadian Covid-19 di Indonesia belum sama sekali berakhir. Angka kejadian relatif menurun saat ini, tapi masih harus perlu kewaspadaan. Pada saat kegiatan ini dilaksanakan, Indonesia pada kondisi menghadapi serangan kedua kejadian Covid-19. Angka kejadian ini merata hampir di semua daerah, khususnya di Solo Raya termasuk Kabupaten Karanganyar. Upaya edukasi, sosialisasi untuk pelaksanaan 3M (Menjaga jarak, Memakai masker, Mencuci tangan) di awalnya, kemudian diperkuat menjadi 5M - ditambah dengan Menjauhi Kerumunan serta Membatasi mobilitas (telah dengan masif dilakukan), akan tetapi dalam pelaksanaannya masih banyak terjadi pelanggaran dan kurangnya kesadaran untuk secara disiplin menerapkan.

Penularan penyakit infeksi termasuk Covid-19 tidak terlepas dari interaksi antara agen penyebab penyakit -host dan lingkungan. Upaya peningkatan daya tahan tubuh host agar dapat bertahan terhadap serangan virus juga merupakan hal yang penting dilakukan. Banyak faktor yang mempengaruhi daya tahan individu/ host, antara lain dengan makanan yang bergizi, istirahat cukup, olah raga teratur, dan menghindari stress. Untuk itu perlu pengetahuan pemilihan makanan dan minuman yang dapat meningkatkan imunitas seperti herbal. Pemanfaatan bahan alam sebagai produk herbal untuk memperkuat imunitas telah banyak berkembang dengan banyak bukti klinis pendukung.

Yayasan Usaha Umat Karanganyar (YUUK) sebagai mitra kegiatan adalah satu yayasan dalam bidang sosial keagamaan di wilayah Buran, Tasikmadu Karangayar, Jawa Tengah. Yayasan ini didirikan dengan tujuan meningkatkan kebermanfaatan manusia atas manusia yang lain dalam bidang agama, ekonomi dan sosial. Tujuan ini dilaksanakan melalui kegiatan pendidikan, pelatihan, dakwah, ekonomi dan sosial. Salah satu sasaran pembinaan adalah melalui remaja masjid. Menurut Siwanto (2005) remaja masjid adalah suatu organisasi atau wadah kerja sama bagi remaja untuk melakukan kegiatan bersama dan mencapai tujuan bersama ${ }^{1}$. Remaja masjid merupakan wadah utama dalam pengkaderan bidang kemasjidan terhadap generasi muda ${ }^{2}$. Selama ini kegiatan remaja masjid telah rutin dilakukan dalam bidang dakwah keagamaan, ekonomi, pelatihan, dan sosial.

Keberadaan remaja masjid merupakan potensi untuk menjadi kader penggerak dalam upaya pencegahan Covid-19. Peningkatan pengetahuan remaja menjadi dasar untuk menggerakkan lingkungannya guna mencegah dan mengurangi penyebaran virus corona (Covid19) yang semakin meningkat saat ini dengan cara yang benar. Riset Grup TRIMED merancang pengabdian ini berupa pemberdayaan remaja masjid dalam usaha pencegahan wabah Covid-19, dalam hal ini dengan memberikan percontohan pembuatan minuman herbal sederhana. Selain dengan makanan, menjaga imunitas juga bisa dilakukan dengan herbal, sehingga remaja masjid juga diberikan tambahan pengetahuan bagaimana membuat minuman herbal dari bahan sederhana yang tersedia di sekelilingnya untuk meningkatkan imunitas. Tanaman secara keseluruhan atau bagian tanaman (daun, buah, biji, rimpang) memiliki kandungan zat aktif yang dapat dimanfaatkan untuk menjaga kesehatan, termasuk meningkatkan imunitas ${ }^{3}$. Kandungan bahan aktif yang bermanfaat tersebut antara lain senyawa polifenol seperti flavonoid yang dapat berkhasiat sebagai antioksidan ${ }^{4,5,6}$. Mengingat khasiat minuman herbal untuk menjaga imunitas sebagai upaya pencegahan COVID-19, maka tujuan kegiatan pengabdian ini untuk mensosialisasikan dan mendemonstrasikan cara pembuatan minuman herbal sederhana berbahan dasar jahe. 


\section{METODE}

Pengabdian ini dilakukan dalam beberapa tahap:

1. Assesment: merupakan tahap awal yang dilakukan untuk menilai/melakukan analisis situasi beserta kelengkapan yang dibutuhkan. Data yang diperoleh dari mitra menunjukkan masyarakat sekitar dari sosial ekonomi menengah ke bawah, dengan kesadaran akan pentingnya kesehatan masih perlu ditingkatkan. Ini terbukti dari kondisi MCK (mandi, cuci, kakus) yang belum memadai, pembuangan sampah masih sembarangan, budaya merokok tinggi dan kesadaran memakai masker kurang. Pada saat perencanaan kegiatan, sejalan dengan peningkatan prevalensi penyakit Covid-19 di Jawa Tengah, sehingga perlu penerapan protokol kesehatan serta penguatan imunitas dengan makanan bergizi serta herbal. Perlu edukasi pada masyarakat dalam memilih dan menggunakan makanan yang bergizi serta pemanfaatan herbal untuk meningkatkan immunitas ${ }^{5}$. Remaja masjid dipandang mampu menjadi agen untuk menyebarkan pengetahuan tersebut, sehingga dipilih kelompok remaja masjid sebagai sasaran kegiatan.

2. Koordinasi: diskusi internal kelompok RG TRIMED untuk pembagian tugas pelaksanaan kegiatan; pemilihan serta penyusunan materi pengabdian. Koordinasi juga dilakukan dengan narahubung Yayasan Usaha Umat Karanganyar untuk kelancaran pelaksanaan kegiatan.

3. Pelaksanaan edukasi: pelaksanaan edukasi di lokasi dengan model ceramah tanya jawab disertai demonstrasi. Kegiatan ini dilaksanakan pada tanggal 13 Juni 2021 WIB bertempat di Masjid Asy Syakur, Desa Buran, Tasikmadu Karanganyar. Jumlah peserta 45 orang remaja masjid serta 10 orang pengurus Yayasan Usaha Umat Karanganyar dan takmir masjid. Pemateri adalah Joko Sudarsono, S.Farm., MPH., Apt.

Ceramah sebelum demontrasi bertujuan untuk menyampaikan peran herbal dalam menjaga imunitas dan bagaimana cara membuat minuman herbal sederhana berbahan dasar jahe. Demonstrasi pembuatan minuman herbal sederhana menggunakan alat: media edukasi (LCD proyektor dan lap top), kompor, panci, gelas, dan sendok. Adapun bahan-bahan yang digunakan antara lain jahe 2 siung, sereh 1 lembar, daun jeruk 4 lembar, gula jawa 1 atau sesuai selera, dan air $300 \mathrm{ml}$.

Cara membuat:

1. Bakar jahe di atas kompor sampai timbul bau wangi, kemudian tumbuk sereh.

2. Didihkan air sebanyak $300 \mathrm{ml}$ didalam panci.

3. Setelah mendidih, masukkan bahan satu persatu ke dalam panci mulai dari jahe, sereh, daun jeruk dan gula jawa. Aduk hingga merata dan ditunggu kira-kira 5-10 menit sampai air didalam panci sedikit menyusut dan timbul wangi yang khas.

4. Matikan kompor, lalu pindahkan jamu ke dalam gelas dan ditunggu sampai jamu bisa diminum. Peserta dibagikan sampel jamu yang dibuat untuk diminum. 


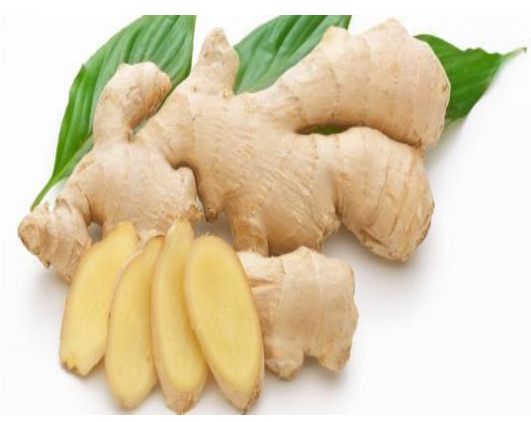

Gambar 1. Contoh rimpang jahe ${ }^{6}$

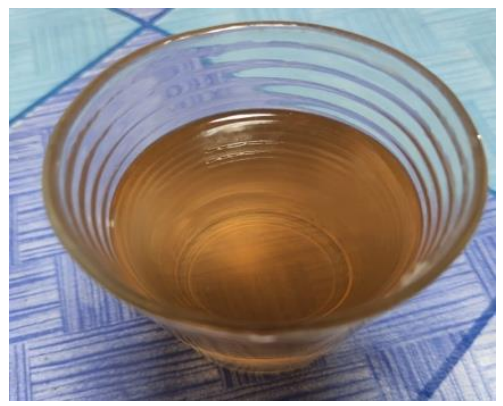

Gambar 2. Minuman sari jahe (Sumber: primer)

\section{HASIL DAN PEMBAHASAN}

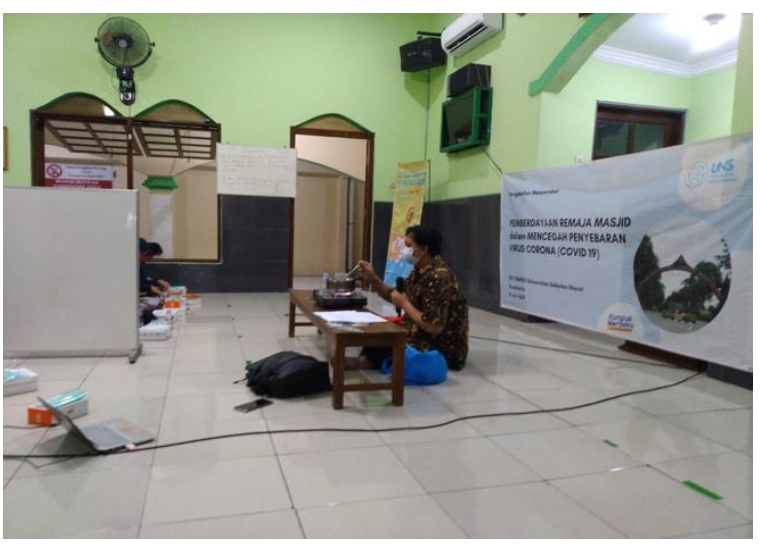

Gambar 3. Paparan narasumber (Sumber: primer)

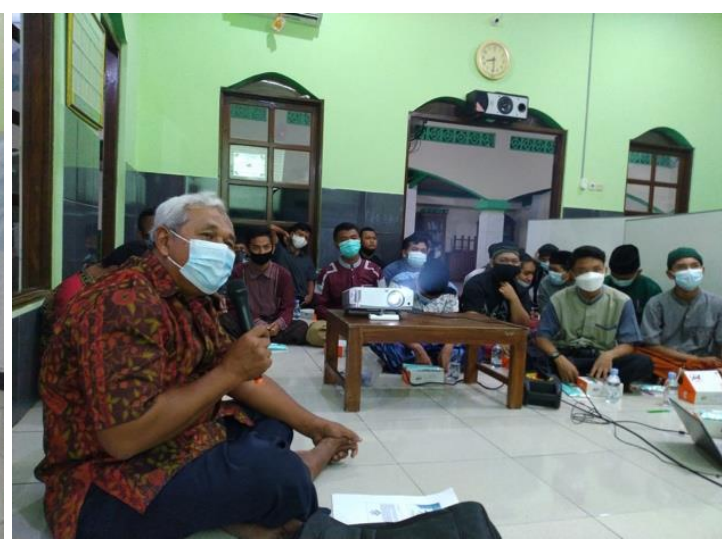

Gambar 4. Peserta edukasi (Sumber: primer)

Dari paparan narasumber, peserta antusias mendapatkan pemahaman, terlihat dari sesi diskusi. Peserta menyatakan mendapat pengetahuan baru dalam pemanfaatan bahan alam dari bumbu dapur menjadi jamu untuk meningkatkan imunitas. Sebagian peserta baru mengetahui bahwa pembuatan minuman herbal tersebut ternyata mudah, rasanya enak dan segar. Penjelasan dan demontrasi diberikan untuk memberikan pengetahuan manfaat jahe untuk imunitas serta memberikan contoh cara membuat dan mengolah obat tradisional di rumah tangga. Selain jahe, bahan nabati yang bisa dimanfaatkan antara lain adalah kunyit, temulawak, juga jambu biji, sambiloto, dan meniran. Pada kegiatan ini dipilih jahe karena rasa yang relatif bisa diterima banyak orang selain efek utamanya dalam meningkatkan imunitas. Jahe merupakan tanaman herba menahun yang tumbuh subur di daerah tropis, termasuk Indonesia ${ }^{3,4,7}$. Di Indonesia sendiri, tanaman jahe juga sudah dibudidayakan di seluruh daerah di Indonesia. Bagian utama jahe yang sering dimanfaatkan adalah rimpangnya. Rimpang jahe secara umum digunakan secara luas sebagai bumbu dapur dan obat herbal untuk bermacam jenis penyakit. Di antara beberapa varietas yang ada, pemanfaatan jahe varietas emprit lebih banyak digunakan untuk produk olahan minuman jahe karena kandungan minyak atsirinya lebih tinggi dibanding varietas lain, sehingga rasanya lebih pedas ${ }^{4,6}$. Di antara yang didiskusikan dalam sesi tersebut adalah:

1. Manakah jenis jahe yang bisa dimanfaatkan: pada dasarnya baik jahe putih yang besar (jahe gajah), jahe kecil (emprit) dan jahe merah bisa dimanfaatkan tetapi rasa nya akan sedikit berbeda karena kandungan minyak atsiri berbeda. Jahe besar relatif kurang pedas disbanding jahe emprit. Menurut Hapsoh et al (2010) jahe besar sering digunakan untuk manisan atau makanan lain karena rasanya yang tidak terlalu pedas ${ }^{4}$. Jahe merah memiliki kandungan zat 
aktif lebih banyak dan rasa pedas lebih kuat. Sebagai tanaman obat dengan banyaknya kandungan zat aktif akan memiliki efek yang lebih baik ${ }^{3}$

2. Apakah mengolah jamu sendiri ini aman: jika digunakan sesuai dosis/ petunjuk dan tidak berlebihan jamu aman digunakan, kecuali jika orang tersebut alergi terhadap bahannya. Perlu diperhatikan juga penyimpanan bahan sebelum digunakan agar tidak mudah tumbuh jamur dan juga penyimpanan setelah diolah. Lebih baik jika segera diminum. Penyimpanan jahe sebaiknya di tempat yang bersih, tidak lembab, dengan ventilasi udara baik tapi tidak terkena matahari langsung 3,4 .

3. Apakah manfaat jahe: dalam masa pandemi ini tujuan utama mengkonsumsi jahe adalah untuk meningkatkan imunitas. Tetapi banyak bahan aktif dalam jahe yang bisa dimanfaatkan untuk tujuan kesehatan lain. Senyawa gingerol dalam jahe dapat dimanfaatkan sebagai pereda nyeri ${ }^{9}$.

\section{KESIMPULAN}

Kegiatan edukasi pembuatan minuman herbal sederhana berbahan dasar jahe ini telah dilaksanakan dan dapat menambah pengetahuan pada Remaja Masjid tentang manfaat jahe untuk meningkatkan imunitas dan cara membuatnya.

\section{UCAPAN TERIMA KASIH}

Terima kasih kepada:

1. Universitas Sebelas Maret yang telah mendanai kegiatan ini dengan RKAT PTNBH Universitas Sebelas Maret tahun anggaran 2021 melalui skema pengabdian kepada masyarakat hibah grup riset (PkM-HGR-UNS) dengan Nomor Kontrak 261/UN.27.22/HK.07.00/2021.

2. Yayasan Usaha Umat Karanganyar yang telah menyediakan tempat dan bersedia bermitra.

\section{DAFTAR PUSTAKA}

1. Siswanto. Panduan Praktis Organisasi Remaja Masjid. Jakarta: Pustaka Al-Kautsar; 2005

2. Yani A. Panduan Memakmurkan Masjid: Kajian Praktis Bagi Aktivis Masjid. Jakarta: LPPD Kahiru Ummah; 2016

3. Dewi YK \& Riyandarai BA. Potensi Tanaman Lokal Sebagai Tanaman Obat Dalam Menghambat Penyebaran Covid-19. Jurnal Pharmascience 2020; 07(02): 112-128. Diunggah dari: https://ppip.ulm.ac.id/journal/index.php/pharmascience

4. Hapsoh Y, Hasanah E. \& Julianti. Budidaya Dan Teknologi Pasca Panen Jahe. Medan: USU Press; 2010.

5. Faznur LS, Santoso G, Hidayati N. Pemanfaatan Rempah-Rempah Pada Era New Normal Untuk Meningkatkan Imunitas Kekebalah Tubuh Di Lingkungan Warujaya. Prosiding Seminar Nasional Pengabdian Masyarakat LPPM UMJ. Website: http://jurnal.umj.ac.id/index.php/semnaskat.

6. Kusumo AR, Wiyoga FY, Perdana HP, Khairunnisa I, Suhandi RI, Prastika SS. Jamu Tradisional Indonesia. Journal of Public Service 2020; 4(2): 465-471.

7. Lukito AM. Petunjuk Praktis Bertanam Jahe. Jakarta: Agromedia Pustaka; 2007

8. Kritikar KR. \& Basu BD. Indian Medicinal Plants. $2^{\text {nd }}$ Edition. India: International Book Distributers; 2007.

9. Singh G, Kapoor IS, Singh P, Heluani CS, Lampasona MP, Catalan C. Chemistry, Antioxidant And Antimicrobial Investigation On Essential Oil And Oleoresin Of Zingiber Officinale. Food Chemistry Toxicol 2008; 46: 3295-3302. 